
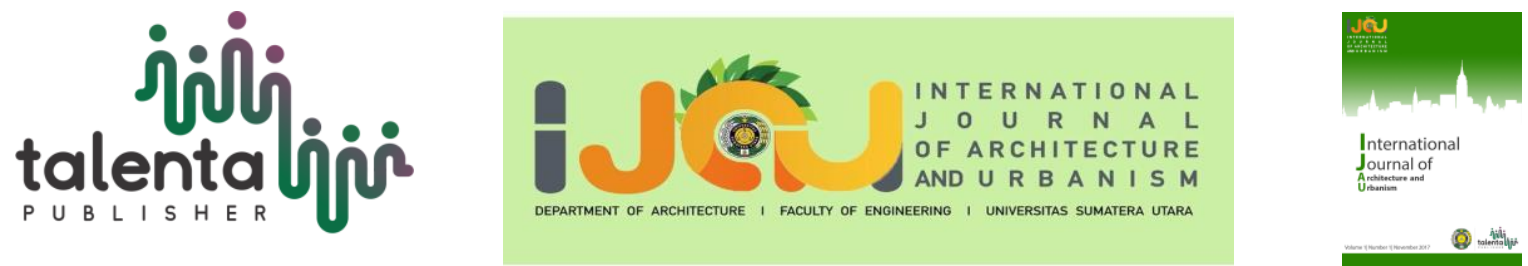

\title{
Sipiso-Piso Hotel Resort and Cottage (Neo-Vernacular Architecture)
}

\author{
Stella Bornok Ristamora ${ }^{1 *}$, Firman Eddy ${ }^{1}$ \\ ${ }^{1}$ Department of Architecture, Faculty of Engineering, Universitas Sumatera Utara, Medan, Indonesia
}

\begin{abstract}
Hotel Resort and Cottage is a facility that will later help to develop culture, tourist attractions and also increase regional income. Until 2017 infrastructure development in Indonesia, in general, cannot be said to be equitable because so far, infrastructure development is only concentrated in Java and infrastructure development outside Java which, is less especially in remote areas and border areas. However, this issue canaddress by increasing Regional native revenue (PAD). Indonesia is known as a diverse country of natural and cultural resources, can be the main attraction in the tourism sector to bring domestic and foreign tourists to the area. The methodology applied from the design of this resort hotel and cottage is research directly to the location to see the soil conditions, contours, facilities around the area, wind direction, view, and sunlight. It is also a reference to some of the existing literature regarding resort hotels and cottages. The area selected for this project is Sipiso-Piso, Saribu Dolok Street, Merek District, Karo Regency because of the many resources that can manage optimally. This place has the potential to be used as a tourist attraction as well as a cultural development place. However, this place lacks facilities and infrastructure. After identifying the needs of generator activities, researchers make the design of Hotel Resort and Cottagein, addition to improving tourist sites and cultural education, this design also aims to increase the revenue of this area. Analysis and design concepts using the interpretation of Neo Vernacular Architecture
\end{abstract}

Keyword: cottage, hotel resort, neo-vernacular

Received 05-06-2020 | Revised 01-07-2020 | Accepted 17-07-2020

\section{$1 \quad$ Introduction}

In the Bukit Sipiso-Piso area, are still minimal facilities for tourist attraction. Unfortunately, such a nifty asset from the existence of a tourist attraction has not to managed optimally, even though the natural panorama at this place is very pulling. In the Opinion of Schmidt, "The panorama of nature will improve the quality of tourist sites that have been visiting to come back because of its beautiful natural attractions." According to the study 5 Elements of Tourist Attractions in the Sipiso-Piso, based on Waterfall Tourism Region Geopark, the majority of respondents argue that cultural activities in the area are very lacking. It is due to existing

\footnotetext{
*Corresponding author at: Department of Architecture, Faculty of Engineering, Universitas Sumatera Utara, Perpustakaan Street, J07 Building, Medan 20155, Indonesia
} 
cultural activities in the Sipiso-Piso are only held at certain times and still not the Calendar of Event. Elements included in natural attractions can be Panorama, Flora and Fauna, Climate, Parks, and Conservation Areas [1]. This result in tourists can not see local cultural attractions. Though traditional events or cultural festivals are events that tend to attract attention, most tourists see the attractions of a culture that can be used characteristics of the culture in the tourist area and make a difference from the culture in other tourist attractions [2]. Also, in the region, the cultural characteristics of the Toba Batak culture are still unclear. From the statement above, the designer chose a resort hotel and cottage as a case in this project. The Design of Resort and Cottage Hotels applies Neo Vernacular Architecture.

\section{Literature Review}

In the opinion of Prof. Fred Lawson, "Hotel defines a public establishment offering travelers, against payment, two basic accommodation and catering services" [3]. In the opinion of Dennis L. Foster, " The Cottage is a type of accommodation located around the beach or lakes in the form of separate buildings, for rent for families, individuals equipped with recreational facilities. " [4]. According to Chuck Y. Gee in his book, "Resort Development and Management, WatsonGuptil Publication (1988), " The Resort is a well-planned area not just to stay but also for rest and recreation [5]. A Resort Hotel should have land related to the attraction. Therefore a Resort Hotel is located on hills, valleys, small pulung, and also coastal suburbs [6]. The theme applied in the design of this Resort Hotel is Neo-Vernacular. NeoVernacular architecture is an architecture whoseconcept considers normative, cosmological, local culture in community life and harmony between buildings, nature, and the environment [7]. Neo-Vernacular Architecture is one of the ideas or the flow that developed in the PostModern era, namely the flow of architecture that emerged in the mid-1960s. In essence, NeoVernacular architecture is a blend of modern buildings with brick buildings (local material) in the 19th- century.

Background on the application of Neo-Vernacular Architectural themes on the design of Resort Hotels and Cottages is to improve tourist areas and cultural identity and harmonize between nature and culture in the Sipiso-Piso Hill area with elements modern developing to be more attractive to tourists. The Vernacular Architectural Context with the local resource environment which is built by the community using simple technology to meet the needs of characteristics that accommodate values the economic and cultural structure of the people of that society is. Not only modern physical elements applied in the Neo vernacular architecture but also nonphysical elements such as culture, mindset, beliefs, layout, religion, and others.

According to Charles A. Jencks in his book, "Language Of Post-Modern Architecture (1990), " can be described as the characteristics of Neo-Vernacular Architecture as follows always use a roof [8]. Always use the roof of pillars. Roof roofs cover the level of the walls until almost to 
the ground so that more roofs which described as protective elements and welcomer of the wall depicted as a defense element symbolizing Hostility; Bricks (in this case are local construction elements). The building predominantly by the use of 19th-century Victorian brick that is a culture of western architecture; Restore traditional forms that environmentally friendly in more vertical proportions; Unity between open interiors through modern elements with open space outside the building; Strong colors and contrast.

\section{Methodology}

The location selection method based on several things, namely overview of the city structure, based on the Karo Regency Spatial Plans (Rencana Tata Ruang Wilayah) 2012-2032, region Sipiso-Piso, Tongging, Kecamatan Brand included in tourist sites; Achievement, the design location can be achieved through several alternative roads and vehicles with relevant mileage; Service area, the building service area to be designed can serve tourists coming; Soil and land conditions, Soil and land conditions are exceptional, and there are steep contours and there not.

The design approach used in the design of Sipiso-Piso Resort and Cottage Hotels are Field study is environmental analysis, condition around the site, potential, the boundaries of the site; The site and environmental approach are to analyze the conditions and the best solutions for the design; A user approach that analyzes buildings to meet the needs of a recreational facility; Literature studies related to titles and themes, as well as theories that support design ideas.

\section{Result and Discussion}

The theme used as a design concept is Neo-Vernacular Architecture. The design location in the Sipiso-Piso area has many natural and cultural resources enough can be removed from the region. The design location is in the transition area between the Karo and the Simalungun Batak. Moreover, at this location, there is still no cultural identity clear. Therefore, the Toba Batak culture raises in the area. Neo-Vernacular Architecture Theme applies to the composition of the mass, the main building, the Hotel, and the Cottage. In addition to the location of the region, the design made an "Area Traditional Village and Museum," where the pattern settlement is adopted, and adjustments made to the shape and location of the location and surroundings (Figure 1).

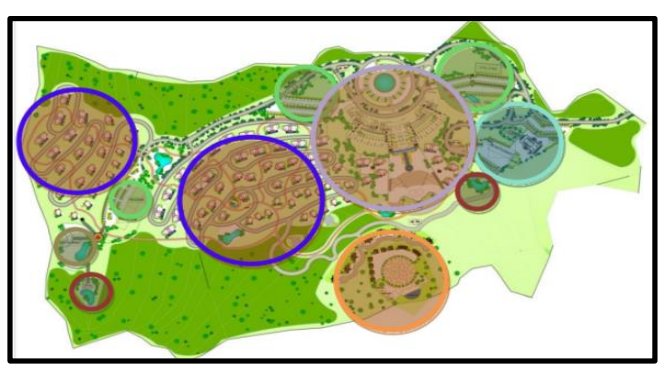

Figure 1 Masterplan 
The site divided into six zonings, namely cottage area, hotel, traditional village, museum, parking area, restaurant, and spa. In this design, outer space becomes a crucial element because it has a good impact on the success of this tourist area. Therefore, the space facilities outside connect the design area. Outdoor recreation facilities offered in the design of this region varies, among others walking garden is in the cottage zone, in this area, visitors can be circling the flower garden while passing through an integrated fish pond walking garden. Besides walking garden is a separator between facilities existing in the design area; the concept of Fruit Garden Area, the orchard area, is in the entrance lane of visitors to the area. It positions due to the consideration of land use and accessibility. Also, visitors who enter the area can feel the atmosphere of the area greet by the area orchard. The choice of fruit determined whether it will be fertile or not in the area. In addition to the orchard area, facilities also provided in the form of fruit markets and juice. Visitors can walk around the garden and pick fruit directly, then take it to the fruit market and juice to make a drink fresh. The hotel consists of three upper floors and five lower ground floors-many facilities provided in the hotel (Figure 2).

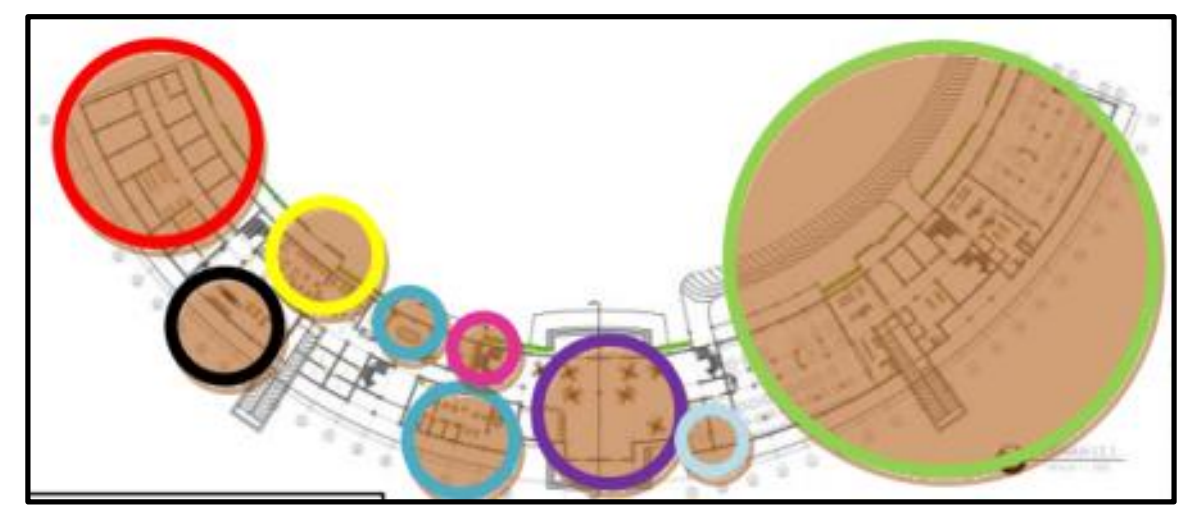

Figure 2 Zoning Lower Ground floor Hotel

The lower ground floor divided into eight zonings, namely service area, laundry, fitness center, toilet, hall, souvenir, and restaurant. All rooms on the ground floor are public and service functions. All rooms on the ground floor are public and service functions. The second to fourth floors serve as private rooms of different types on each floor (Figure 3).

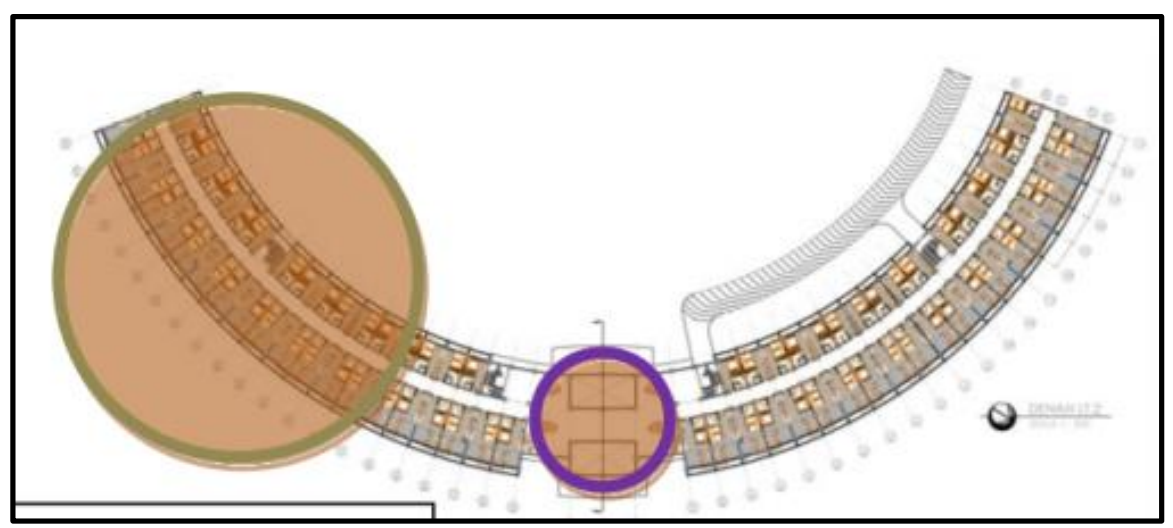

Figure 3 Zoning FL. 2-3, LG 1-4 
The second to third floors and first to fourth lower ground floor only divided into two zonings, the hall, and the room. On this floor, there are two types of rooms, namely a superior room with a capacity of two people with one master bedroom and a deluxe room with a capacity of two people. Deluxe rooms have two types of beds, one is a master bedroom, and there are two single beds. There is a seating area of $2.5 \times 3$ meters (Figure 4).

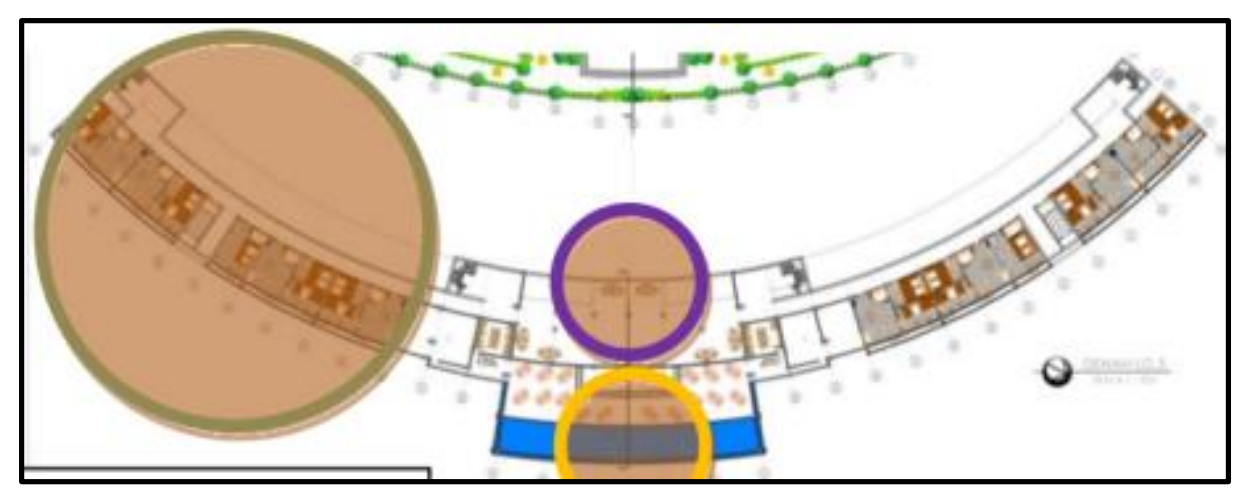

Figure 4 Zoning FL. 5

The fifth lower ground floor divided into three zonings, namely the rooms, the halls, and swimming pools. On this floor, the type of room provided is a suite room. This room type has two rooms, one room with one master bedroom, and another with two single beds, with each room measuring $4.5 \times 5$ meters. This suite room also provides a sitting room with a size of $5 \times 3$ meters, and there is a dining room. Besides hotels, there are also three types of cottages, and each cottage has a private pool (Figure 5).

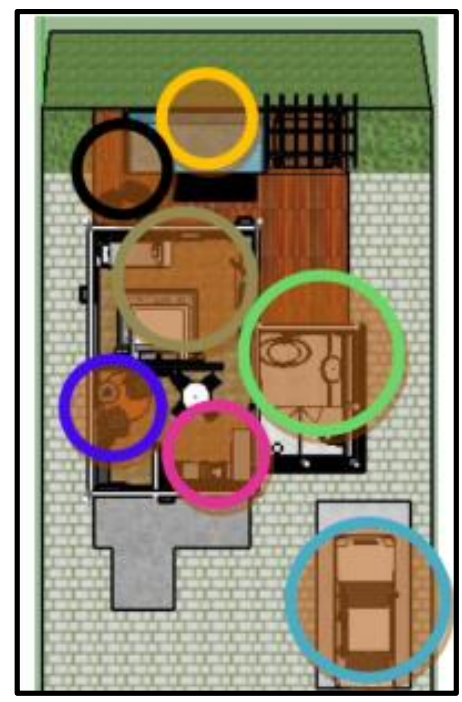

Figure 5 Zoning Superior Cottage

The superior cottage divided into seven zonings, namely infinity pool, outdoor seating, master room, bathroom, sharing room, kitchen, and parking. A superior cottage is the smallest type. This type measures $8 \times 14$ meters. The capacity of this superior cottage is two people with one master bedroom type (Figure $6 \& 7$ ). 


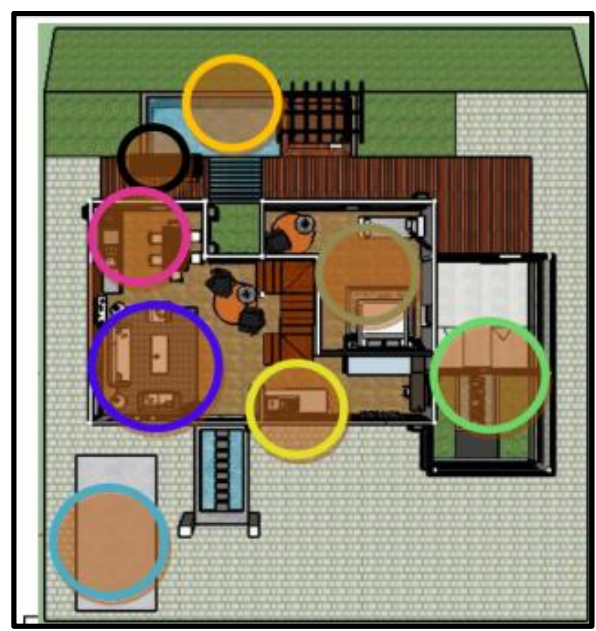

Figure 6 Zoning Suite Cottage

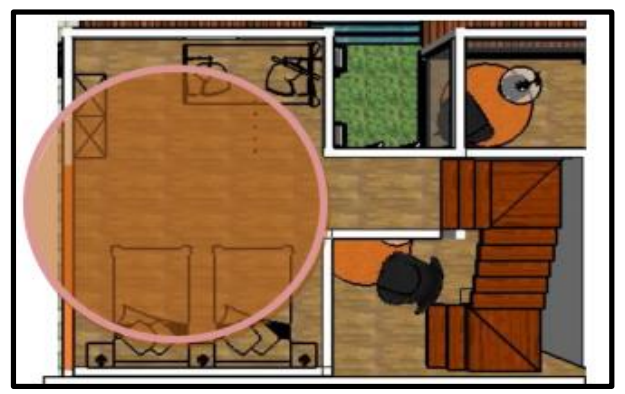

Figure 7 Zoning Mezzanine Suite Cottage

Suites cottage divided into eight zonings, namely infinity pool, outdoor seating, master room, kitchen, bathroom, sharing room, parking, pantry. This type measures $8 \times 16$ meters. The capacity of this suite cottage is four people with one master bedroom and two single beds on the mezzanine floor (Figure $8 \&$ 9).

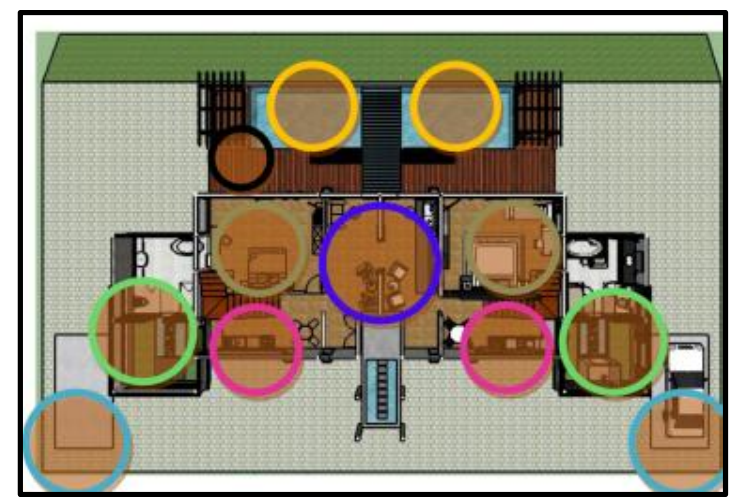

Figure 8 Zoning Family Cottage

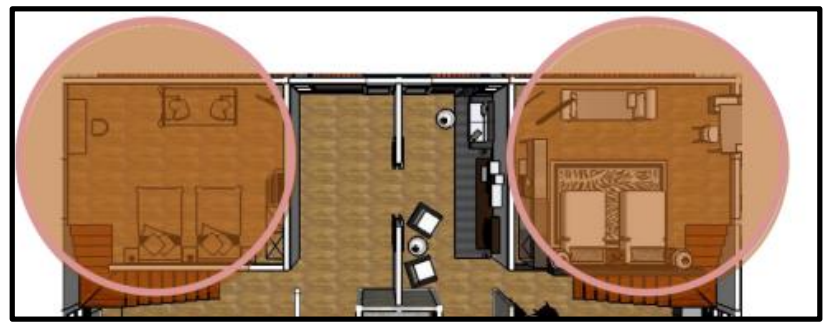

Figure 9 Zoning Mezzanine Family Cottage 
The Family cottage divided into eight zonings, namely infinity pool, outdoor seating, master room, kitchen, bathroom, sharing room, parking, pantry. This type measures $15.5 \times 26$ meters. Family cottage has a connecting door. The family cottage has a connecting door in the middle. Its function is to combine and separate the two parts of the territory within it. The capacity of this suite cottage is eight people with two-room for master bedroom and two-room for single beds on the mezzanine floor (Figure 10).

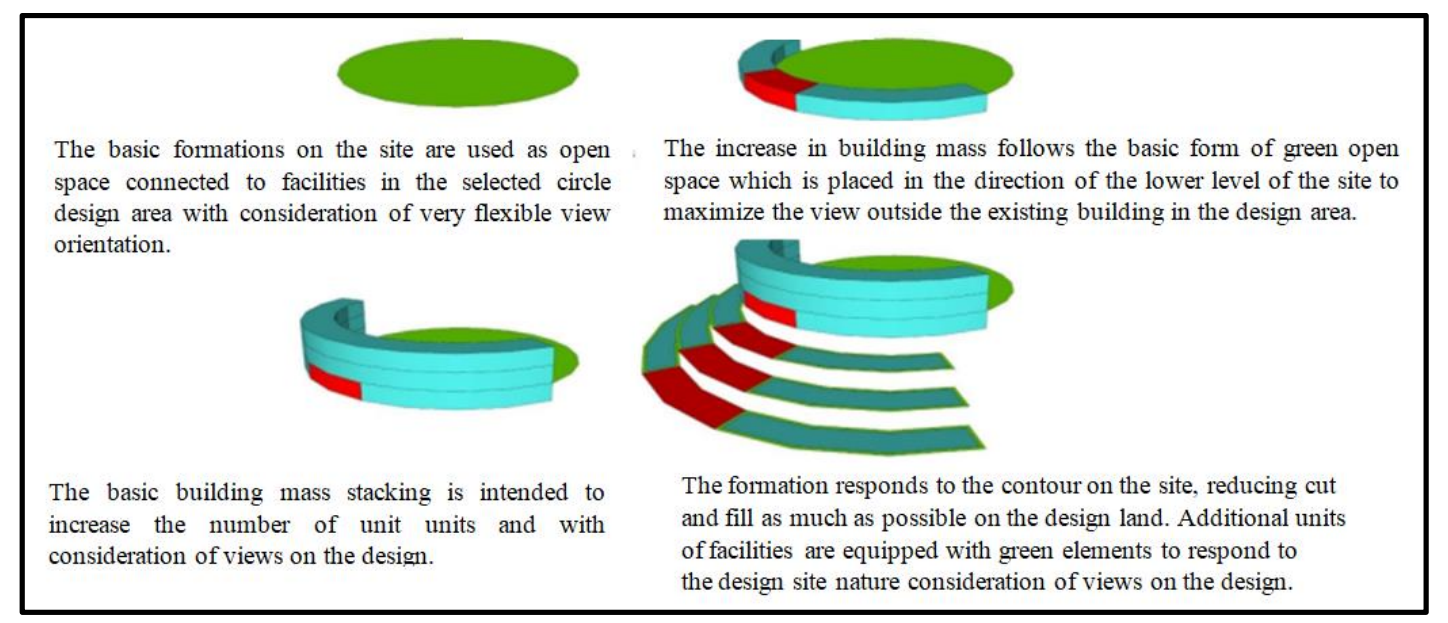

Figure 10 Hotel Mass Form

The hotel resort building is a very form interpretation consider the flexibility of view from inside and outside the building, which designed. The view is the primary consideration in the design on-site, so with a large area design area, it is expected that the design can respond to the flexibility of the view show (Figure 11).

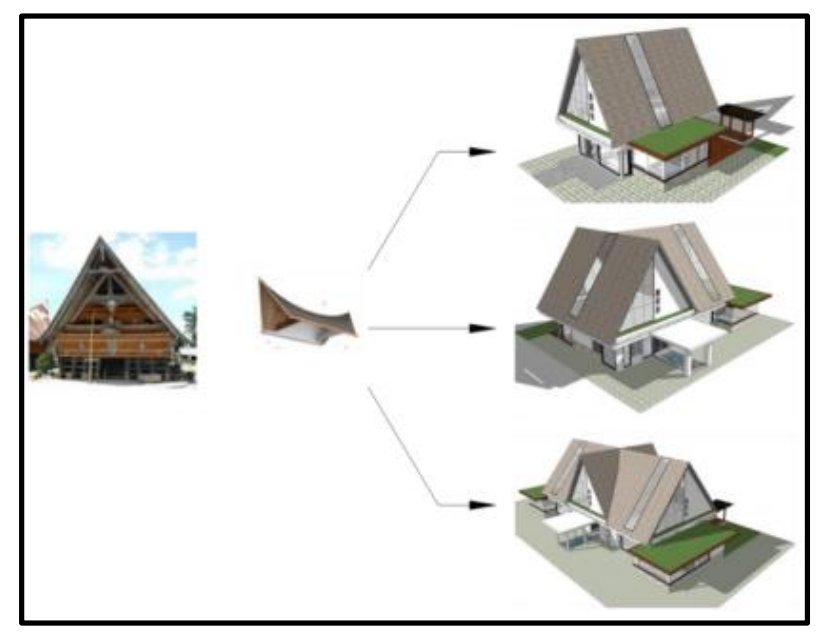

Figure 11 Cottage Mass Form

In the cottage, the mass will use the form of the adopted roof through the traditional Batak Toba traditional house. On the walls of the building will use glass material combined with wood material function as a structure in the designed building. 
The structure in a hotel resort building is a rigid frame structure. Grid the structure is determined by considering the formation of a circular mass such that has a grid parallel to the determination of a certain radius that is the same from the center mass formation. Vertically, the bottom structure uses a bore pile foundation with a $2 \times 2$ meter pile capsize. The building at the bottom follows the leveling contour site so that a retaining wall structure needs on the part of this building. The roof structure uses a semi-form active structure system, so using steel material. The roof structure is connected to a rigid structure building frame with a steel-concrete connection at the highest level of the beam (Figure 12).

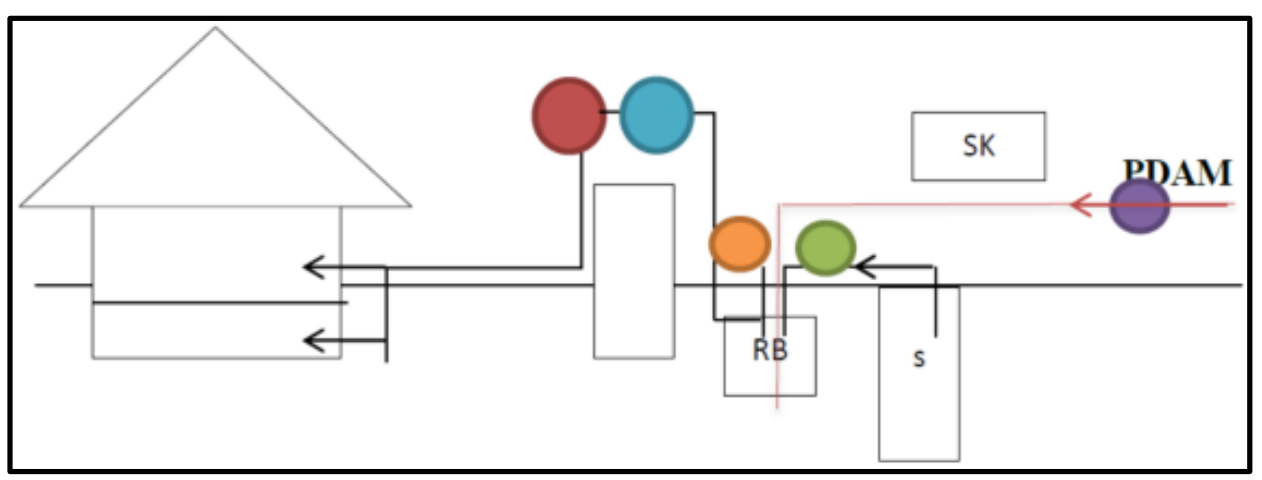

Figure 12 Down Feed Distribution Water With Reservoir

PDAM ( Perusahaan Daerah Air Minum ) is a government-owned business entity region, which carries out service functions generate water needs drinking/clean water for the community, is expected to provide services clean water that evenly distributed to all levels of society, helps developments for the business world and establishing adjusted tariff structures with the level of community capability.The distribution system used is a down-feed distribution system, the clean of water the distribution system in buildings using the bottom reservoir as a medium to accommodate the flow of water supplied by infiltration wells and PDAM before distribution to the upper reservoir by the pump booster. It means that PDAM has two functions, the function of service to the community and the function of increasing the acceptance area [9].

The waste disposal system in the main building, cottage, and other facilities provides by the trash box divided into two parts, viz organic and non-organic, and from garbage collection will be transported to landfill the closest (Figure 13).

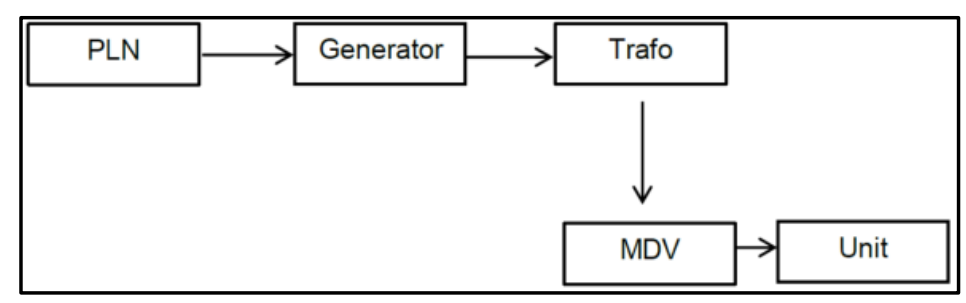

Figure 13 Electricity Distribution 
PLN ( Perusahaan Listrik Negara) is one of the state-owned enterprises (BUMN) which is engaged in the supply of electric power whose very existence needed by the community. BUMN ( Badan Usaha Milik Negara ) State-owned enterprises under Law No. 19 of 2003 is the whole business entity or make it easier for the capital to be owned by the country through direct inclusion that comes from the richness of the country separated [10]. The primary source of electricity in resort hotels and cottages comes from PLN and generators as a backup energy source if the primary electricity source can not use. Then from the generator, electricity flows to the transformer, which serves to transmit electrical energy to low voltage and high voltage. After the transformer, electricity is supplied to the MV-MDV (Medium Voltage Medium Distribution Distribution) to distribute to each targeted unit. (Figure 14).

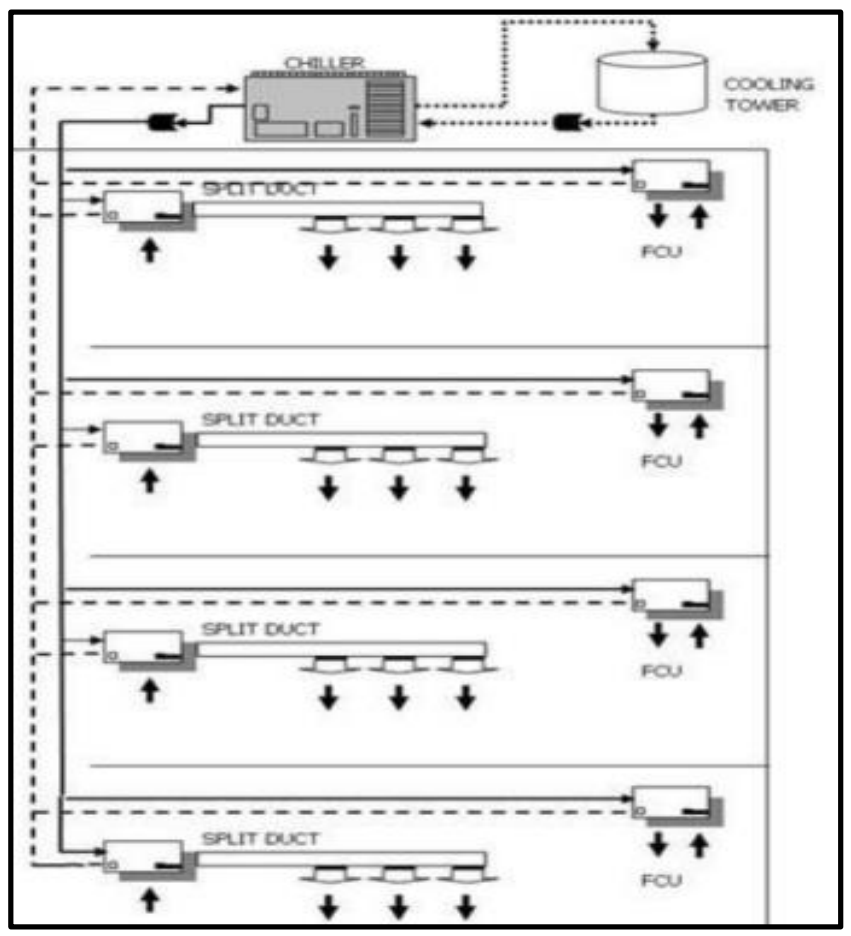

Figure 14 Air Conditioner Distribution

The air conditioning system in the hotel uses Air Conditioner for keeping the temperature of each room to stay airy and superb. Fan coil unit (FCU) is a simple device consisting of a heating or cooling a coil and fan. Split Duct is an AC with which applies a ducting system or duct system using pipes.Basically, this AC can be distributed to several sectors, but the center itself is at one point. A chiller is a refrigeration machine that has the primary function of cooling water on the evaporator side. The resulting cold water distributed to a heat exchanger (FCU/Fan Coil Unit). The ventilation system for cottages does not use ventilation artificial because the weather conditions in the area are cold, then it does not need to use artificial ventilation. Moreover, the position of the cottages is also close to a lake, so lots of cool breezes move around where things are it can use cross-ventilation system used in the primary function Active Protections is Hydrant, Smoke Detector, Fire Alarm, Portable Extinguisher, Sprinkler. 


\section{Conclusion}

The project design of Hotel Resort and Cottage located in the Sipiso-Piso area, which expected to be a tourist activity yours can increase the income of the North Sumatera area. It supported because of a lot of natural and cultural resources sold to tourism who come to the area. The concept used in this area is Neo-Vernacular Architecture, which the design of Buildings and functions in the area takes from Toba Batak culture made to be an identity of the region. The main functions designed in this project are Hotels and Cottage, which designed with local wisdom and conditions in mind around the area. Each result that designed intended to form a recreation area and for A place to rest from all activities.

\section{Acknowledgment}

These researchers have prepared this article and partly funded by the Department of Architecture Universitas Sumatera Utara, a contribution for the city government in planning and design to maintain existing local wisdom.

\section{REFERENCES}

[1] Nurlisa Ginting, Anggun Sasmita, Affilla Syahra, and Putri Harfitalia, Kajian Elemen Atraksi Wisata Pada Kawasan Wisata Air Terjun Sipiso-Piso Berbasis Geopark(Prosiding Seminar Kearifan Lokal dan Lingkungan Binaan 25-26 Januari 2017), 2017.

[2] Rivera et al, Economic Impact of Cultural Events: The Case of The Zora!Festival., 2008.

[3] Fred Lawson, Hotels, Motels, and Condominium : Design, Planning, and Maintenance, The Architectural Press. London, 1976.

[4] Daniel L. Foster, An Introduction to Travel and Tourism., 1997.

[5] Chuck Y. Gee, Resort Development and Management, Watson Guptil Publication., 1988.

[6] Nyoman S. Pendit, Ilmu Pariwisata. Jakarta: Akademi Pariwisata Trisakti, 1999.

[7] Nyoman S. Pendit, Ilmu Pariwisata. Jakarta: Akademi Pariwisata Trisakti, 1994.

[8] C.Jencks, The Language of Post-Modern Architecture, 6th ed. Rizzoli, Italia, 1990.

[9] Syamsudin Alhabsji dan Soedjoto, Kedudukan dan Peranan Perusahaan Daerah dalam Pelaksanaan yang Nyata dan Bertanggung Jawab. Jawa Timur: Universitas Brawijaya, 2001.

[10] Undang-Undang Republik Indonesia Nomor 19 Tahun 2003 Badan Usaha Milik Negara. Jakarta: Lembaran Negara Republik Indonesia Tahun 2003 Nomor 70, 19 Juni 2003. 